\section{Adaptation of Pachysandra terminalis Sieb. \& Zucc. to Freezing Temperatures by the Accumulation of mRNA and Cold-induced Proteins}

\author{
Suping Zhou ${ }^{1}$ and Roger J. Sauvé \\ Institutefor Agricultural and Environmental Research, Tennessee State University, \\ 3500 J.A. Merritt Boulevard, Nashville, TN 37209 \\ Margaret T. Mmbaga \\ Nursery Crop Research Station, 472 Cadillac Lane, McMinnville, TN 37110 \\ Additional index words. antifreeze proteins, cold acclimatization mechanism, cold tolerance, \\ differential display, japanese spurge, mRNA, plant improvement
}

\begin{abstract}
A cold acclimatization mechanism regulated by the accumulation of mRNAs and proteins has been tentatively identified in japanese spurge (Pachysandra terminalis Sieb. \& Zucc.). Two polypeptides and several cDNA fragments were observed in leaf tissue after acclimation. When these proteins were probed with type III fish antifreeze antibodies, an immune-cross reaction occurred. Nonacclimatized young leaves and stems of japanese spurge survived 20 -minute exposures at $-5^{\circ} \mathrm{C}$. Although newly emerged leaves and stems were damaged, plants resumed growth at higher temperatures. After acclimation by gradual cold treatments $\left(4\right.$ to $\left.-5^{\circ} \mathrm{C}\right)$, new proteins began to accumulate in young leaves and plants were more tolerant to extended treatments at $-5^{\circ} \mathrm{C}$. Changes in accumulation of proteins and mRNA in leaf tissue of japanese spurge appear to be an adaptation mechanism to subfreezing conditions. This is the first report of the immune-cross reaction between antibodies of type III fish antifreeze proteins and plant proteins
\end{abstract}

Cold-tolerance is an important trait for ornamental plants. During production, minor phenotypic imperfections in ornamental plants resulting from cold or subfreezing conditions can result in loss of their market value. Each year, abiotic stress from cold temperatures causes yield losses wherever cold-sensitive crops are grown. Plant species vary in their responses to freezing temperatures, some species are able to survive cold stresses by using a super-cooling or a freeze-tolerance mechanism (Anston et al., 2001; Baardsnes and Davies, 2001, Meyer et al., 1999; Worral et al., 1998). An understanding of antifreeze mechanisms in tolerant species is needed for developing strategies to produce cold-resistant cultivars. In this study, we investigated the effects of low temperature treatments on Pachysandra terminalis Sieb. $\&$ Zucc. (japanese spurge). Japanese spurge is an evergreen groundcover cold hardy in most of the 48 U.S. contiguous states. This species is widely planted in shade gardens in USDA zones 4 to 8 .

This study was performed to determine the

Received for publication 2 June 2004. Accepted for publication 28 Sept. 2004. We thank Chris Catanzaro and Nick Gawel, Tennessee State University, for critical review of the manuscript, FurChi Chen for his advice in protein analysis, and Sarabjit Bhatti for her assistance with laboratory bioassays. Antibodies against SP and QAE fragments of type III antifreeze proteins were provided by A.L. Devies, Queensland University, Ontario, Canada. This research was partially funded by two USDACapacity Building Grants (98-38814-6238 and 2002-38814-12598).

${ }^{1}$ To whom all correspondence should be directed; e-mail zsuping@tnstate.edu. been maintained in an unheated cold-frame in Nashville, Tenn., were relocated to a growth chamber at $24 / 20{ }^{\circ} \mathrm{C}$ (day/night) with a $16 \mathrm{~h}$ photoperiod at $30 \mu \mathrm{M} \mathrm{m}^{-2} \cdot \mathrm{s}^{-1}$ flux for deacclimation. After new shoots began to grow (6 weeks at $24{ }^{\circ} \mathrm{C}$ ), the temperature was reduced to 10 ${ }^{\circ} \mathrm{C}$ for 2 weeks before the initiation of coldtreatments. Treatments consisted of exposing 3 whole plants to the following exposures: 5 ${ }^{\circ} \mathrm{C} / 3 \mathrm{~d}, 4{ }^{\circ} \mathrm{C} / 2 \mathrm{~d}, 0{ }^{\circ} \mathrm{C} / 24 \mathrm{~h},-2{ }^{\circ} \mathrm{C} / 2 \mathrm{~h},-2{ }^{\circ} \mathrm{C}$ $/ 20 \mathrm{~min},-5^{\circ} \mathrm{C} / 2 \mathrm{~h},-5^{\circ} \mathrm{C} / 20 \mathrm{~min},-10^{\circ} \mathrm{C} / 30$ min, and $-10{ }^{\circ} \mathrm{C} / 1 \mathrm{~h}$ in a freezer. Following treatments, plants were moved to an incubator at $7{ }^{\circ} \mathrm{C}$ for $24 \mathrm{~h}$ for recovery and later returned to the growth chamber $\left(24 / 20^{\circ} \mathrm{C}\right.$ (day/night). Cold-damage was assessed based on the degree of leaf and stem necrosis and shoot regeneration. Control plants were not acclimatized; they were taken from the greenhouse and immediately subjected to subzero temperatures. For each treatment, 3 plants with an average of 12 shoots each were used.

Newly emerged leaves (young) from each of the 3 plants in each treatment combination (18 treatment combinations) were harvested immediately after each temperature treatment, frozen in liquid $\mathrm{N}_{2}$ and stored at $-70{ }^{\circ} \mathrm{C}$ until tissue analysis.

Leaf protein extraction and Western blot analysis. Frozen leaf samples were homogenized in liquid $\mathrm{N}_{2}$ and mixed with a protein extraction buffer $(2: 1, \mathrm{v} / \mathrm{w})$ and incubated on ice at $0{ }^{\circ} \mathrm{C}$ for $6 \mathrm{~h}(12)$. The extraction buffer consisted of a 1:1 dilution of Tricine sample buffer (Biorad, Hercules, Calif.). Cell debris was removed by centrifugation at $20,000 \mathrm{rpm}$ for 15 min at $4{ }^{\circ} \mathrm{C}$. Protein samples $(15 \mu \mathrm{g})$ were denatured at $100{ }^{\circ} \mathrm{C}$ for $3 \mathrm{~min}$, separated on $10 \%$ SDS-PAGE, subjected to electrophoresis and electroblotted onto an Immobilon-P transfer membrane (Millipore Corporation, Bedford, Mass.). Equivalent loading was verified by staining blots with Ponceau S (Sigma). After blocking for $2 \mathrm{~h}$ atroom temperature and $16 \mathrm{~h}$ at 4 ${ }^{\circ} \mathrm{C}$ in TBST (Tris-buffered saline supplemented with Tween) containing 3\% (w/v) low fat milk powder; blots were probed with the primary antibody, antibodies against SP and QAE fragments of type III antifreeze proteins, and with the secondary antibody IgG-ab7007 (Abcam Ltd, Cambridge, U.K.). Primary and secondary antibodies were diluted 1:100 and 1:500 (v/v), respectively. Chemiluminescence produced by a secondary antibody obtained from Enhanced Chemiluminescence(Pierce, Rockford, Ill.) was detected on radiographic film (12).

$R N A$ fingerprinting using $c D N A$ differential display. ForcDNAdifferential display analysis, leaf samples were removed from plants that received a cold treatment of either $5,0(6 \mathrm{~h})$, and $-5{ }^{\circ} \mathrm{C}(2 \mathrm{~h})$. Plants growing at $24{ }^{\circ} \mathrm{C}$ were used as control. Total RNA was isolated from each leaf sample with the B10101 FastRNAkitGreen (Q-BIOgene, Rutherford, Calif.), and tested for DNA contamination in formaldehyde agarose gels. Only pure RNAwas used forcDNA synthesis and differential display. The Delta Differential Display PT1173-1 kit (Clontech, Palo Alto, Calif.) and Perkin Elmer radioactive ${ }^{32} \mathrm{p}$-dATPlabel(Albany, Mass.)were used.After amplification, PCR products were separated 
$5 \mathrm{kD}$

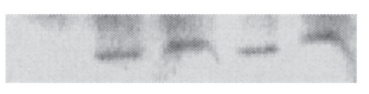

a)

$24 \mathrm{C} \quad 4 \mathrm{C} 0 \mathrm{C}-2 \mathrm{C}-5 \mathrm{C}$

$50 \mathrm{kD}$

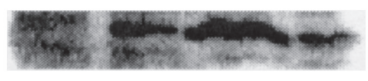

b)

$$
\text { 24C } \quad 4 \mathrm{C} \quad 0 \mathrm{C} \quad-2 \mathrm{C}
$$

Fig. 1. Western blot (a). with AFPIII QAE, (b) with AFPIII SP, (c) with rabbit antiserum.

in $5.5 \%$ denature acryl amide gels and signals were recorded on X-ray film by overnight exposure at $-70{ }^{\circ} \mathrm{C}$. Unique bands present in specific treatments or bands that exhibited differences in intensity were considered to contain DNA fragments of putative low temperature responsive genes.

\section{Results and Discussions}

Fully expanded (mature) green leaves have higher freeze tolerance than newly formed leaves and cold-acclimation improves cold tolerance in newly formed leaves. At temperatures warmer than $-2{ }^{\circ} \mathrm{C}$, young stems and leaves of japanese spurge plants were not damaged. When the temperature was decreased to $-5{ }^{\circ} \mathrm{C}$ for 20 min, young stems and leaves of nonacclimated plants were damaged or killed while acclimated ones were not. The survival rates of acclimated plants were $100 \%$ and $90 \%$ for young shoots (stems) and leaves, respectively while the rate for nonacclimated plants was $70 \%$ for both young shoots and leaves. Assessments were tabulated by counting the leaves and stems on each plant that recovered after plants were returned to room temperature. However, when the coldtreatment was extended to $2 \mathrm{~h}$, the survival rate of acclimated plants was $90 \%$ and $50 \%$, young shoots and leaves, respectively while it was only $15 \%$ for nonacclimated plants (young shoots

Fig. 2. cDNA profiles of cDNA differential display. Arrows indicate bands that differed between treatments: 1) $24{ }^{\circ} \mathrm{C}$; 2) $5{ }^{\circ} \mathrm{C}$ for $15 \mathrm{~d}$, 3) $0{ }^{\circ} \mathrm{C}$ for $24 \mathrm{~h}, 4) 5^{\circ} \mathrm{C}$ for $2 \mathrm{~h}$.

P1 P2
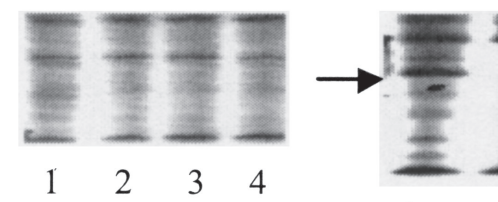

1

23

\section{$\mathrm{kDa}$}

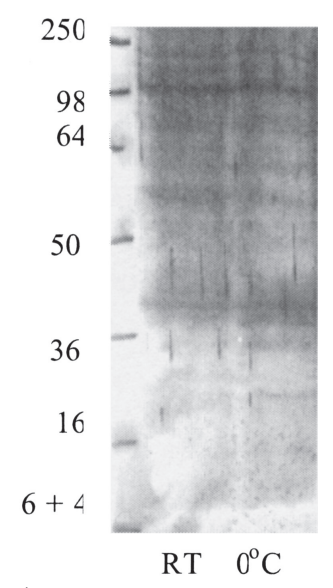

c)

$$
\text { RT } \quad 0^{\circ} \mathrm{C}
$$

New proteins accumulated after plants were subjected to low temperature treatments. To detect for possible accumulation of new proteins in leaves of japanese spurge, Western blot analysis was performed with leaf proteins probed with antibodies produced against different fragments of fish AFPIII proteins. After treatments at $4,0,-2$, and $-5^{\circ} \mathrm{C}$, new proteins began to accumulate in young leaves. Two new peptide bands (about $50 \mathrm{kDa}$ against $\mathrm{SP}$ and $5 \mathrm{kDa}$ against QAE (Fig. 1a and b) were detected in all leaves probed with antibodies of type III antifreeze proteins after being subjected to temperatures $<4{ }^{\circ} \mathrm{C}$. These bands were not detected in the Western blot assay against rabbit pre-serum (Fig. 1c).

This is the first report of the immune-cross reaction between antibodies of type III fish antifreeze proteins and plant proteins. Results suggest that similarities in the epitope structure of proteins identified in japanese spurge and in fish exist. Presently, we are purifying these proteins to determine conclusively their homology to AFP III proteins by using peptide mapping and amino acid analysis.

Regulation of gene transcription is involved in cold tolerance of japanese spurge. To test whether gene transcription is being regulated during the acclimation process, we carried out RNA fingerprinting using cDNA differential display (Leong et al., 2002; Zhou et al., 2002). Some genes maintained a constant transcription level (Fig. 2, P1), while others were down-regulated as indicated by lower intensities of cDNA bands following cold treatments (Fig. 2,P2). The intensities of some cDNA fragments were higher after low temperature treatments (Fig. 2, P3) and new cDNA bands appeared after cold treatment (Fig. 2, P4). In total, 290 cDNA bands were identified, of which, 152 had higher intensities after cold treatments and the rest had decreased intensities.
Most banding profiles were similar after 5, 0, and $-5^{\circ} \mathrm{C}$ treatments. These results suggest that low temperature treatments can initiate up- and down-regulation of genes that may be participating in the cold acclimation process.

In conclusion, fully expanded leaves and stems of japanese spurge can survive $-5^{\circ} \mathrm{C}$ with no sign of tissue damage. Newly formed leaves from acclimated plants are tolerant to a clodshock at $-5^{\circ} \mathrm{C}$ for $20 \mathrm{~min}$. The accumulation of new proteins and mRNA following exposures to 4 and $5{ }^{\circ} \mathrm{C}$ suggests that alterations in gene expression occur during the process of cold acclimation. Such alterations in gene expression have been reported (Miura et al., 2001).

Sequence analysis and functional characterization of these proteins and cDNA fragments may lead to the identification and isolation of antifreeze genes in japanese spurge for use in genetic engineering of ornamentals to improve their tolerance to freezing temperatures during the growing season.

\section{Literature Cited}

Antson, A.A., D.J. Smith, D.I. Roper, S. Lewis, L.S. Caves, C.S. Verma, S.L. Buckley, P.J. Lillford, and R.E. Hubbard. 2001. Understanding the mechanism of ice binding by type III antifreeze proteins. J. Mol. Biol. 26(4):875-789

Baardsnes, J. and P.L. Davies. 2001. Salic acid synthase: The origin of fish type III antifreeze protein? Trends Biochem. Sci. 26(8):468-469

DeVries, A.L., S.K. Komatsu, and R.E. Feeney. 1970. Chemical and physical properties of freezing point-depressing glycoproteins form Antarctic fishes. J. BioI. Chem. 245:2901-2908.

Fan, Y., B. Liu, H. Wang, S. Wang, and J. Wang. 2002. Cloning of an antifreeze protein gene from carrot and its influence on cold tolerance in transgenic tobacco plants. Plant Cell Reports 21(2):(in press) $<$ http:/link.springer/service/journals/00299/contents/02/00495/paper/s00299-002-0495>

Leong, P., W.K. Liew, W. Lim, and F.T. Chow. 2002. Differential display rt-PCR analysis of Enterovirus-71 infected Rhabdomyosarcoma cells reveals mRNA expression responses of multiple human genes with known and novel functions. Virology 295(1):147-159.

Meyer K., M. Keil, and J.J. Naldrett. 1999. A leucinerich repeat protein of carrot that exhibits antifreeze activity. FEBS Lett. 447:171-178.

Miura K., S. Ohgiya, T. Hoshino, N. Nemoto, T. Suetake, A. Miura, Spyracopoulos, L.H Kondo, and S. Tsuda. 2001. NMR analysis of type III antifreeze protein intramolecular dimmer. Structural basis for enhanced activity. J. Biol. Chm. 276(2):1304-1310.

Worral, D., L. Elias, D. Asford, M. Smallwood, C. Sidebottom, P. Lillford, J. Telford, C. Holt, and D. Bowles. 1998. A carrot leucine-rich-repeat protein that inhibits ice re-crystallization. Science 282:115-117.

Xu, G.H., Y. Ling, Y. Wan, and S.M. Wang. 1997. Method of mRNA differential display and its application in life science. Sheng Li Ke Xue and Jin Zhan 28(1):19-23.

Zhou, S., R.J. Sauve, S. Bhatti, E. Myles, and F. Chen. 2002. Effect of cold treatments on cDNA differential display in japanese spurge. SNAProc. 47:645-647.

Zhou, S., R.J. Sauve, and E.F. Howard. 2002. Identification of a cell wall peroxidase in red calli of Prunus incisa Thumb. Plant Cell Rpt. 21:380-384. 